\title{
Jakiej filozofii potrzebuje edukacja w świecie XXI wieku?
}

\section{KEYWORDS}

philosophy of education, educate to unknown, digitization, global teenagers, VUCA world

\begin{abstract}
Tatiana Krawczyńska-Zaucha, Jakiej filozofii potrzebuje edukacja w świecie XXI wieku? [What is the philosophy of education needed in the XXI century?]. Kultura - Społeczeństwo - Edukacja nr 2(18) 2020, Poznań 2020, pp. 455-466, Adam Mickiewicz University Press. ISSN 2300-0422. DOI 10.14746/kse.2020.18.17.1

The last decades have witnessed constant changes and reforms in education in many countries. The paradox of these changes is that they require further changes and transformations and further reforms. Education systems do not correlate with the needs of humanity in the 21 st century, nor with the emerging new world view. This article aims to examine education from the global perspective of the world of digitization in which we live and to find an answer to the question what is the purpose of education in the 21 st century. From the analyses of different pedagogical trends and philosophical assumptions underlying them, a conclusion will be drawn about the need for a philosophy open to new challenges in today's educational reality in order to achieve this goal. This article will address key issues of the VUCA world concerning education such as digitization, educate to the unknown, the phenomenon of global teenagers and the development of robotics.
\end{abstract}

Instytucjonalizacja i egalitaryzm paradoksalnie sprowadziły edukację do roli obszaru zamkniętego w opasłych tomach biurokratycznych procedur, odbierając jej jednocześnie nieznośną lekkość pasji i niecierpliwość ciekawości. W dzisiejszych czasach dyskusje na temat edukacji koncentrują się zatem wokół jej formy, która

\footnotetext{
* ORCID: 0000-0001-6530-4206.
} 
została wysoce zinstytucjonalizowana, podporządkowując jej treść doraźnym interesom polityczno-gospodarczym. Choć jakość jest częścią formy edukacji, zostawia się ją raczej na marginesie działań biurokratycznych. Można pokusić się o stwierdzenie, że historia zatoczyła smętne koło - pomimo tego, że edukacja jest powszechnie dostępna, nie spełnia już swojej pierwotnej funkcji oświecania i pobudzania umysłów, lecz ginie w mroku niepamięci i rozproszenia po przymusowej, lecz krótkotrwałej memoryzacji. Nawet Rawls, który postulował „sprawiedliwą równość szans" (1971: 72) dla dzieci ze wszystkich klas i warstw społecznych, nie mógł przewidzieć, że dostęp do edukacji niekoniecznie oznacza motywację do zdobywania wiedzy. Co zatem zostało pominięte lub przeoczone?

Aby nie zgubić się w gąszczu znaczeń oraz podejść do pedagogiki i edukacji, warto wrócić do źródeł. Paidagogos (gr.) to ktoś odpowiedzialny za prowadzenie dzieci, zajmowanie się ich rozwojem i wychowaniem, sprawujący nad nimi opiekę i troskę (Śliwerski, 2019: 15). Filozof Radim Palouš wskazuje nawet, że istotą pedagogiki jest to, co zawiera się w formacie przyrostkowym agogé (gr.) pochodzącym od agein (prowadzić) lub age (wieść ku górze) (Palouš, 1991: 16-17). Pedagogikę można zatem zdefiniować jako „wszelkie warunki, procesy i działania wspierające rozwój jednostki ku pełnym jej możliwościom” (Kwieciński, Śliwerski, 2019: 7).

Edukacja natomiast wywodzi się z łac. educo, gdzie $e$ jest przedrostkiem oznaczającym ruch na zewnątrz, zaś duco to prowadzenie. Większość tłumaczeń skupia się na drugiej części słowa, podkreślone jest znaczenie pojęcia edukacji jako prowadzenia, wychowywania, kształcenia. Aby jednak zrozumieć jej istotę, należy wziąć pod uwagę całe słowo wraz z przedrostkiem $e$ podkreślającym ruch $\mathrm{z}$ wewnątrz na zewnątrz. Wówczas edukacja jawi się jako wydobywanie z wnętrza ucznia jego osobistych zasobów, talentów i mocnych stron, umożliwiając mu ich używanie w świecie (Krawczyńska-Zaucha, 2020: 68).

Wychodząc z takiej nieoczywistej w dzisiejszych czasach perspektywy, wszelkie działania pedagogiczne, jak i edukacyjne powinny ze swej natury skupiać się na prowadzeniu „ku górze” i wydobywaniu na zewnątrz tego, co uczeń ma w sobie, umożliwiając mu życie pełne możliwości, wykorzystanie swojego potencjału i mocnych stron oraz używanie talentów. Stać się to może dzięki życzliwemu towarzyszeniu pedagoga w procesie poznawania siebie i doświadczania świata, który dzieli się z uczniem wiedzą i rozbudza ciekawość poznawczą oraz naukową.

O ile pedagogika skupia się na jednostce i budowaniu twórczej relacji pedagog uczeń, o tyle edukacja to raczej systematyczne i zorganizowane działania obejmujące wszystkie szczeble nauczania (por. Kwieciński, Śliwerski, 2019: 7). W dzisiejszym świecie nie można jej jednak ograniczać do instytucji odpowiedzialnych stricte za kształcenie. Role edukacyjne przyjmują również szeroko pojęte media, imprezy 
masowe, świat reklamy i marketingu czy popularni wśród młodzieży idole, twórcy swoistych subkultur. Niebagatelną rolę, o ile nie najważniejszą, odgrywa również sieć internetowa oplatająca glob, nie tylko ze względu na trudne do ogarnięcia probabilistycznie sieci społecznościowe czy algorytmy mogące realnie wpływać na wybory ludzi (Fry, 2019). Współczesne pokolenia są przecież pierwszymi w historii, które mają dostęp do całej, wypracowanej przez tysiąclecia wiedzy ludzkości. Nigdy wcześniej nie było takiej możliwości. Kiedyś wiedza i osiągnięcia były raczej lokalne, rozprzestrzeniały się miesiącami czy latami. Dzisiaj wystarczy odpowiedni research w Internecie i Philosophiae naturalis principia mathematica Newtona czy On the Origin of Species Darwina w oryginale mogą pojawić się na ekranie w zaledwie kilka sekund.

Zatem rolą edukacji ${ }^{1}$, jej celem, jest twórcze i otwarte na możliwości oraz potencjał wewnętrzny ucznia przygotowanie go do życia w świecie. Tymczasem nietrudno zauważyć, że dzisiejsza edukacja skupia się raczej na odtwórczym przekazywaniu części wiedzy konwencjonalnych dziedzin nauki, bez wzięcia pod uwagę zainteresowań ucznia, jego talentów i mocnych stron. Ken Robinson ujął sedno współczesnej edukacji w przemawiającym obrazie linii produkcyjnej uczniów, którym bez ich zgody wtłacza się do głowy odpowiednią porcję wiedzy, by na koniec otrzymać kolejną partię identycznych, ale sfrustrowanych pracowników, gotowych wypełniać polecenia przełożonych w godzinach pracy, a nawet poza nimi (Robinson, 2012). Jednocześnie opublikowany w październiku 2019 r. Raport o szkolnictwie niepublicznym w Polsce wskazuje, że liczba wszystkich niepublicznych placówek edukacyjnych w kraju wzrosła od 2014 roku do 2018 roku o 17,15\%, a liczba uczęszczających do nich uczniów w tym samym okresie - o 29,73\% (Our Kids, 2019: 8). Te dane wskazują na dynamiczny rozwój szkolnictwa niepublicznego i jego wzrost w ogólnym systemie edukacji w Polsce. W sektorze publicznym widać odwrotną tendencję. Okres 2014-2018 owocuje tendencją spadkową zarówno w liczbie szkół publicznych na wszystkich etapach nauki, jak i w liczbie uczniów kształcących się w tych placówkach. Przekłada się to także na spadek ogólnego udziału edukacji publicznej w kraju (Our Kids, 2019: 8). Przyczyn jest wiele, warto jednak przytoczyć jeden z wniosków raportu:

Wygląda na to, że sektor niepubliczny stanowi dla wielu rodzin oazę, gdzie dzieci mogą znaleźć bezpieczne środowisko, wsparcie (także profesjonalne w postaci logopedów czy psychologów), gdzie docenia się nie tylko ich stopnie i akademickie sukcesy, gdzie dba się o wszechstronny rozwój dzieci, a w miejsce stresu pojawia się radość i dowartościowanie (Our Kids, 2019: 38).

${ }^{1}$ Z przedstawionych rozważań wynika, że edukacja to zorganizowane czynności pedagogiczne podejmowane na wszystkich szczeblach państwa, dlatego w dalszej części artykułu słowa edukacja i pedagogika będą traktowane synonimicznie. 
Nauczanie niepubliczne trafia w potrzeby edukacyjne człowieka XXI w. Proponuje inną filozofię podejścia do nauczania i do samego ucznia. Dba o jego wszechstronny rozwój, uczy pozytywnie patrzeć na siebie i na swoje osiągnięcia, proponuje współpracę i nastawienie na indywidualne wsparcie w rozwoju talentów i zainteresowań. Wszystko to jest osadzone również w innym obrazie świata. Właśnie dlatego, że świat XXI w. charakteryzuje się permanentną zmianą, bez ociężałej machiny biurokracji szkoły niepubliczne i społeczne dużo szybciej są w stanie dostosować się do zmieniających się potrzeb uczniów i oczekiwań ich rodziców oraz dopasować do nich ofertę edukacyjną.

Edukacja publiczna zostaje daleko $\mathrm{w}$ tyle $\mathrm{w}$ stosowaniu elastycznych rozwiązań. Jest osadzona w świecie, którego stabilność sankcjonowana jest przez hierarchię, ustalone struktury i przypisane funkcje, jest obrazem świata ery przemysłowej XVIII i XIX w. Rewolucja przemysłowa umożliwiła przejście z zależnych od pogody i woli Boga plonów pracy rąk własnych do wytwórstwa na większą skalę. Zmieniła też myślenie człowieka o samym sobie, udowadniając, że sprytniej i więcej może on zdziałać intelektem niż wytwórstwem własnych rąk. Zastosowanie silników parowych w różnych gałęziach przemysłu przeniosło więc niezliczone rzesze rolników z pól do podmiejskich fabryk, gdzie ich nędzny widok prowokował wykształconych i bogatych do poprawy ich losu. Głównym celem był powszechniejszy dostęp do edukacji, a kluczowym argumentem - większa wydajność pracowników mających podstawowe umiejętności czytania, pisania i liczenia. W takim hierarchicznym świecie powstał model edukacji autorytarnej oparty na przekazywaniu wiedzy, którą należało powtarzać aż do pamięciowego opanowania, jak instrukcję. Nauczyciel jest tym, który ma wiedzę, a uczeń tym, który stojąc niżej w hierarchii, ma słuchać pedagoga i uczyć się. W takim modelu cele nauczania leżą poza uczniem, nie jest ważne, jakie są jego zainteresowania czy zdolności, ważny jest natomiast wzorzec kształcenia, „pakiet” wiedzy, który ma on opanować, aby stać się użytecznym dla społeczeństwa. Dany wzorzec powinien być identyczny dla wszystkich uczniów z odpowiedniej warstwy społecznej, taką oświatę najłatwiej kontrolować na wszystkich szczeblach (por. Kosiorek, 2010: 146). Nie wymaga się zatem od uczniów kreatywności, innowacyjności ani krytycznego myślenia, kluczowe jest nauczenie się podanych informacji, krok po kroku, aż do opanowania całej wiedzy z odpowiadającego wzorca. Spełnienie stawianych przed uczniem wymagań owocuje otrzymaniem dyplomu - formalnego potwierdzenia uzyskanego poziomu wykształcenia. Należy podkreślić, że pakiet jest traktowany jako kaganek oświaty, za który należy być wdzięcznym. Stopień hierarchii natomiast określa intensywność tej wdzięczności oraz kierunek wpływu: na ucznia ma wpływ nauczyciel, na nauczyciela - dyrektor, na dyrektora - kurator itd. Porządek 
został ustalony, a próba zmiany lub przeciwstawienia się systemowi jest traktowana jako anarchia. Hierarchiczny obraz świata z ustalonym porządkiem i przypisanymi miejscami wynika z przyjętej filozofii człowieka. Empiryczno-behawioralne podejście zakłada, że poznanie uogólnionych praw warunkujących procesy nauczania umożliwi, na podstawie wystarczającej ilości danych empirycznych, zaprojektowanie i zastosowanie swoistego taśmociągu edukacji produkującego kolejnych „wykształconych uczniów”. Behawioryzm zaś dostarczy odpowiednich bodźców sterujących zachowaniem tak, by móc osiągnąć oczekiwane, z góry zaprogramowane rezultaty. Murem obronnym takiego porządku świata jest przekonanie, że powinien on być bezwzględnie zachowany, a tych, którzy mu się przeciwstawiają, należy wykluczyć (por. Hejnicka-Bezwińska, 1995).

Pęknięcie $\mathrm{w}$ murze autorytarnego podejścia $\mathrm{w}$ pedagogice $\mathrm{z}$ pewnością przyniósł początek XX w. Niewypowiedziany koszmar, jaki w czasie wojen zgotował człowiek człowiekowi, zachwiał spiżowym pomnikiem przydatności dobrego wychowania, a nawet edukacji w ogóle. Z jednej strony obraz świata wyłaniający się po wojnach, a nawet, o zgrozo, korzystający z ich „naukowych” osiągnięć zapowiadał nadejście ery technologicznej. Z drugiej - filozofia człowieka początków XX w. podkreślała dramat i bezsens egzystencji ludzkiej pomimo możliwości, jakie stawiał przed nim rozwijający się świat. Szybki postęp dokonujący się w naukach fizycznych, a potem biologicznych, niespotykane wcześniej możliwości i rezultaty, jakie on umożliwił, zmieniały hierarchiczny obraz świata na świat nieograniczonych możliwości uzyskanych dzięki nauce i zaangażowaniu w konsekwentne dążenie do założonych celów.

Dramat dwóch wojen wpłynął na wyłonienie się kilku nurtów pedagogicznych: nurtu pedagogik egzystencjalnych, które kładą nacisk na specyficzność i konkretyzm ludzkiej egzystencji oraz podkreślają jej zmienność, nurtu pedagogik antyautorytarnych jawiących się jako opozycja do wychowania autorytarnego, które mogło doprowadzić do Holokaustu, oraz nurtu personalistycznego w pedagogice podkreślającego wartość i wolność każdej osoby ludzkiej.

Pedagogika egzystencjalna, w różnych swoich wydaniach, zwraca uwagę na indywidualizm człowieka. Chociaż, co podkreślał Heidegger, tłum społeczeństwa zagrzebuje jednostkę w anonimowej masie, narzucając jej konwencjonalne wzorce zachowań (1931: 167), choć człowiek zawsze w tym świecie czuje się obcy (Camus, 1971: 93), to jednak jest możliwe stawanie się sobą dzięki refleksji (Jaspers, 1932, t. 1: 253) i twórczemu działaniu (Marcel, 1962: 186). Novum filozofii człowieka w pedagogice egzystencjalnej, w stosunku do pedagogiki autorytarnej, polega na postawieniu w centrum wolności człowieka stanowiącej cechę wyróżniającą go spośród pozostałych istot, a nawet na dopuszczeniu w ogóle wolności 
jednostki i możliwości decydowania o samym sobie. Takie spojrzenie zdecydowanie przekracza fundamentalne podejście pedagogiki autorytarnej i umożliwia powstawanie kolejnych podejść edukacyjnych: pedagogiki antyautorytarnej oraz personalistycznej. Uzupełniają one egzystencjalną koncepcję człowieka o postulat całościowego podejścia, bez jednostronności i redukcjonizmu. Według pedagogiki personalistycznej edukacja powinna umożliwiać rozwój całej osoby, gdyż „wychowanie to procesy pozwalające istocie ludzkiej odnaleźć się w swym człowieczeństwie" (Schaller, 1977, t. 1:248). Owo odnajdywanie się w swym człowieczeństwie dokonuje się najpierw dzięki samej naturze, ale zaraz potem konieczne staje się otwarcie na kulturę: nabywanie cech i sprawności umożliwiających personalizację osoby, kierując ją na drogę autonomicznych i spójnych wyborów. To główny cel tej pedagogiki.

Podobne podejście charakteryzuje nurt pedagogik antyautorytarnych, również zrodzonych z poczucia rozpaczy nad działaniami ludzkości podczas II wojny światowej. Pierwotnie jej twórca, Adorno, postulował, że pedagogika powinna być w tym sensie antyautorytarna, że wychowywałaby nowe społeczeństwa do życia bez konieczności stosowania przemocy, tak aby nigdy nie powtórzył się koszmar Oświęcimia. Wzywał on nauczycieli do kreowania pedagogiki tolerancji i miłości (1978), co sprzyjałoby budowaniu społeczeństwa opartego na równości, sprawiedliwości i szczęściu (Śliwerski, 2019: 536). Adorno podkreślał konieczność zmian systemowych w oświacie umożliwiających takie podejście pedagogiczne. „Ważnym postulatem dla antyautorytarnych pedagogów stało się obnażanie wszelkich barier instytucjonalnych, blokujących jednostce [...] możliwości budowania tożsamości” (Śliwerski, 2019: 537). Pedagogika antyautorytarna skoncentrowana jest na swobodnym rozwoju osobowości dziecka (Śliwerski, 2019: 538), bez niedopowiedzeń, tabu czy wydawania precyzyjnych instrukcji i oczekiwania ślepego posłuszeństwa. Nauczyciel buduje swój autorytet na relacji współtworzonej z dzieckiem, gdzie to ono wyznacza drogi zainteresowań, kierując się własną pasją. Pedagog kierowany troską i pełen wiedzy podąża za dzieckiem. Nie ma potrzeby stosowania środków przymusu czy przemocy fizycznej, bo uczeń nie musi zmuszać się do uczenia się czegoś, co go nie interesuje. Relacja uczeń - nauczyciel zbudowana jest na obustronnym zaufaniu, budowaniu partnerstwa i dialogu. Dziecko nie czuje strachu przed niewypełnieniem poleceń, ponieważ odpowiedzialność za zdobywanie wiedzy i naukę jest powierzona jemu samemu. Sprzyja to budowaniu w uczniach postawy opartej na poczuciu sprawczości i odpowiedzialności za własne życie i własne wybory, jednocześnie wzmacniając motywację wewnętrzną. Wydaje się, że pedagogika antyautorytarna odwołuje się do humanizmu, bywa też w literaturze stosowana 
zamiennie z pedagogiką humanistyczną ${ }^{2}$, bazuje na personalizmie i libertarianizmie. Trudno jednoznacznie określić granice wspomnianych nurtów edukacyjnych, gdyż zazębiają się ze sobą. Niemniej jednak bez przypisywania któregokolwiek z nich jednoznacznie do którejś konkretnie filozofii można pokusić się o jej scharakteryzowanie dla nich razem. Taka filozofia człowieka bazuje na arystotelesowskim postulacie, że w człowieku istnieją naturalne skłonności do dobra, a szczęście może on znaleźć we własnym wnętrzu, gdyż jest do tego uzdolniony (Arystoteles, 1997: 1094 b 27 n). W dziecku tkwi potencjał, a nauczanie powinno pomóc go wydobyć i rozwinąć, szczególnie w naturalnym otoczeniu (Rousseau). Powinno ono przebiegać w poszanowaniu wolności ucznia, we wspieraniu jego twórczości i kreatywności oraz współpracy z innymi (Dewey). Wolność osobista dziecka jest ograniczona wolnością drugiego człowieka (Lock), a otwartość na świat i pasja jego poznawania mogą się przerodzić w zdolność dorosłego do uprawiania nauki (Schulz, Gopnik, 2004: 27).

Przykładów szkół, programów, a nawet państwowych systemów oświaty, które spójnie i z obiektywnie mierzalnymi sukcesami realizują humanistyczną pedagogikę, jest już dzisiaj wiele. Jednym z nich może być szkoła Summerhill założona przez Neilla w 1924 r. w Anglii. Stała się ona wzorem dla szkół demokratycznych na całym świecie, a publikacje Neilla wywarły ogromny wpływ na dyskurs o wychowaniu permisywnym na całym świecie ${ }^{3}$. Odrzucał on radykalnie jakiekolwiek narzucanie dziecku własnej osobowości w próbie „ukształtowania” jego charakteru. Uważał, że zarówno rodzice, jak i nauczyciele nie wychowują dziecka, lecz manipulują nim dla osiągnięcia własnych celów lub je tresują na własne podobieństwo (1975: 20-22). Postulował traktowanie dzieci jak partnerów i zachęcał do budowania harmonijnych stosunków między światem dzieci a światem dorosłych. Taka postawa wymaga radykalnej przebudowy filozofii człowieka, przyjęcia założeń, że dziecko jest wolne i dobre ze swej natury, że niczego w nim nie trzeba poprawiać, a jedynie umożliwić mu harmonijny rozwój w bezpiecznym i pełnym akceptacji środowisku. Neill wprowadził pojęcie samoregulacji, które oznacza, że dziecko otwarte na swój organizm i swoje potrzeby samo potrafi regulować ich zaspokajanie, rolą dorosłego jest umożliwienie mu tego. Celem wychowania jest człowiek w pełni wolny, harmonijny, spójny i świadomy tego, kim jest, co potrafi i kim chce się stać jako dorosły (Neill, 1969: 40). Warto podkreślić to, co często staje się zarzutem wobec pedagogiki humanistycznej - wolność nie oznacza samowoli i deptania za-

\footnotetext{
${ }^{2}$ W literaturze można spotkać zarówno synonimiczne podejście, jak i rozłączne. Ze względu na ich filozoficzne korzenie w tym artykule będą one traktowane synonimicznie (Januszewska, 2002).

${ }^{3}$ Szkoła Summerhill jest traktowana zarówno jako przykład nurtu antyautorytarnego, jak i humanistycznego (Śliwerski, 2019: 541; Januszewska, 2002).
} 
sad oraz innych ludzi. Wolność jest jedną z najwyższych ludzkich wartości i jako taka zawiera w sobie m.in. równość jednostek wobec siebie, wewnętrzną oraz zewnętrzną możność bycia sobą i samourzeczywistniania swoich naturalnych talentów, ale też respektowanie autonomii i suwerenności innych osób (Śliwerski, 2019: 541). Trudno nie usłyszeć tu postulatów Rawlsa o zachowaniu wolności i dążeniu do ugruntowania dobra własnego, które jednocześnie podtrzymuje układ dążenia do dobra współdzielonego (Rawls, 1994: 214), czy filozofii wolności Steinera, na podstawie której powstała pedagogika i według której prowadzone są szkoły w Europie i na świecie (Steiner, 1984).

Najbardziej znanym państwowym systemem oświaty, który został diametralnie przebudowany w ciągu zaledwie kilkunastu lat, jest Finlandia. Kraj ten położył ogromny nacisk na odpowiednie tak teoretyczne, jak i praktyczne przygotowanie nauczycieli do wykonywania zawodu. Nie wdając się w szczegóły, które można obecnie znaleźć w obszernej literaturze, warto zwrócić uwagę na to, że tworząc nowy system edukacji państwowej, zbudowano go na swoistej filozofii człowieka wraz z czytelnymi dla wszystkich wartościami: partnerstwo, szacunek, współtworzenie, wolność, współodpowiedzialność. System edukacji nie stawia przed uczniami i nauczycielami teoretycznych wymagań, lecz konsekwentnie i spójnie wciela te wartości w życie. Finowie mówią: „Możemy przygotować dziecko do egzaminów lub do życia. Wybieramy to drugie". W efekcie, rozbudzając pasję, kreatywność i poczucie sprawczości uczniów, osiągają oba cele jednocześnie: dzieci zdają testy najlepiej na świecie i są radosnymi, czerpiącymi z życia pełnymi garściami ludźmi (PISA, 2000, 2003, 2006).

Przywołane powyżej nurty pedagogiczne można obserwować w dzisiejszych czasach w różnych ich wersjach, czasem czystych, ale nierzadko mieszanych. Ewoluowały one proporcjonalnie do czasu oddalania się od wojennych dramatów, by coraz bardziej orientować się w kierunku podkreślania wolności człowieka, umożliwienia jednostce pełnego rozwoju własnej osobowości, talentów i zainteresowań, a sam przekaz wiedzy zindywidualizować jak najbardziej pomimo prowadzenia go w grupach. Działania i postawy, które w jednych opcjach edukacyjnych opartych na konkretnym podejściu do człowieka w danym obrazie świata wydają się niemożliwe, zrealizowano w pełni w innych. Przyjęty obraz rzeczywistości wraz z podejściem do człowieka opartym na konkretnych przekonaniach i kierowany wybranym zestawem wartości warunkuje działania.

W tym miejscu konieczne staje się rozszerzenie perspektywy i spojrzenie, jaki obraz świata wyłania się z dzisiejszej rzeczywistości. W latach 90. XX w. powstała pierwsza sieć społecznościowa classmate.com. Dwadzieścia pięć lat później tylko trzy największe portale społecznościowe skupiają ponad 5 miliardów aktywnych 
użytkowników z całego globu (Kallas, 2019). Algorytmy stosowane w Internecie zbierają mnóstwo osobistych danych o osobach z nich korzystających. Spersonalizowane reklamy, wyświetlanie dostosowanych treści do zainteresowań użytkownika czy proponowanie treści, które „lubią użytkownicy tacy jak ty”, to tylko niektóre z przykładów, jak można wpływać poprzez nie na zachowania i decyzje ponad połowy ludzkości (Fry, 2018: 61-66). Dostęp do sieci umożliwił powstanie nowej kategorii młodzieży, tzw. global teenager (de Mooij, 2013: 13). To pokolenie nastolatków, którzy, choć mieszkają w różnych częściach świata, np. w Tokio, Nowym Jorku, Paryżu, Singapurze czy Warszawie, swoim zachowaniem, poglądami i planami bardziej są podobni do siebie nawzajem niż do swoich rodziców czy innych pokoleń, wśród których się wychowali i wśród których żyją (de Mooij, 2013: 13-14). Global teenagers ubierają się według tej samej mody, słuchają tej samej muzyki, oglądają te same filmy na YouTube, jedzą junk food tak samo jak ich rówieśnicy z drugiego końca globu, wyznają podobne, globalne wartości (de Mooij, 2013: 14). Dzisiejszy człowiek żyje w globalnym świecie Internetu i jest uwikłany w rządzące nim algorytmy. Sieć wpływa nie tylko na zachowania ludzi, lecz także zmienia tożsamość człowieka w XXI w. Ale to nie wszystko.

Mimo że 25 października 2017 roku był z pewnością jednym z wielkich dni kolejnej rewolucji w historii ludzkości, mało kto w Polsce wie, co się wówczas wydarzyło. Tego dnia humanoid Sophia otrzymał oficjalnie obywatelstwo saudyjskoarabskie, wpisując się tym samym w historię ludzkości jako pierwszy robot, który kiedykolwiek otrzymał obywatelstwo (Hatmaker, 2017). Ludzkość, karmiona filmami o buntach robotów, boi się włączania humanoidów do swoich społeczności. To jednak nie roboty stanowią dzisiaj wyzwanie dla człowieka, lecz robotyzacja pracy (Harari, 2018: 101-105). Zautomatyzowana produkcja czy usługi będą mogły zatrudniać zaledwie promil tych osób, które zatrudniają dzisiaj. Co będzie w tym czasie robił przeciętny człowiek? Co powinien umieć i jaką musi mieć wiedzę? To są pytania stojące przed edukacją XXI w., sięgające korzeniami filozofii świata i filozofii człowieka ${ }^{4}$.

Dowody na to, że młodym ludziom potrzebne są zupełnie nowe umiejętności, których nie kształtuje wystarczająco skutecznie szkoła, pochodzą nie tylko z obserwacji życia codziennego i opinii wyrażanych w mediach. Z badań Banku Światowego wynika, że tzw. soft-skills są najbardziej deficytowym zestawem umiejętności poszukiwanym przez pracodawców (Bank Światowy, 2011: 13). Uczeń, potem student, przyswaja zaledwie wiedzę teoretyczną, nie ucząc się praktycznych umiejętności, te nabywa dopiero w zakładzie pracy. Podobnie jest z całym zesta-

\footnotetext{
${ }^{4} \mathrm{~W}$ przytoczonych powyżej przykładach także etyki, ale to nie jest miejsce na takie rozważania.
} 
wem kompetencji społecznych: komunikacją, krytycznym myśleniem, rozwiązywaniem problemów, pracą projektową, współpracą w zespole itd.

Wydaje się, że w świetle powyższych przykładów pytanie o to, jakiej edukacji potrzebuje człowiek w XXI w., jest tylko pytaniem retorycznym, ponieważ odpowiedź jawi się sama. Główny prąd edukacji powinien zostać wybrany na podstawie obecnego obrazu świata, ale również mając na uwadze to, jaki obraz wyłoni się w najbliższej przyszłości. Dzisiejszy świat nie koresponduje z pedagogiką autorytarną, która choć krytykowana przez dziesięciolecia, dalej trzyma się dobrze w systemach oświaty wielu krajów. Wychowanie w duchu posłuszeństwa, jedynej słusznej odpowiedzi na zadane pytania, a przede wszystkim powielania „pakietów” wiedzowych i światopoglądowych w głowach kolejnych grup uczniów nie jest i nie może być odpowiedzią na cyfrowy świat sieci w XXI w. Niezmiernie ważna jest zatem świadoma odpowiedź na pytanie, jaki jest dzisiaj cel edukacji. Jeśli jest nim przygotowanie do życia w świecie, który jest światem globalnej sieci i wszechobecnych algorytmów podsuwających jednostkom decyzje, w świecie nieustannych i nieoznaczonych zmian, w świecie, który stawia przed ludzkością wyzwania, jakich nigdy przedtem nie było, w świecie, w którym, o ironio, to dzieci i młodzież w pewnych aspektach poruszają się sprawniej i lepiej, to odpowiedzi z pewnością należy szukać w nurtach pedagogik opartych na wolności i koncentracji wokół osiągnięcia pełni człowieczeństwa przez każdego ucznia. Tylko edukacja oparta na filozofii postulującej, że człowiek jest z natury dobry i nie ma w sobie braków, lecz możliwości i potencjał, do którego należy umożliwić mu dostęp, bazujący na własnych talentach i pasji, co otwiera drogę do nieustannego rozwoju, by wreszcie doprowadzić do pełni człowieczeństwa, przygotuje młodych ludzi do życia w cyfrowym świecie XXI w., gdzie zacierają się wszelkie znane granice, ale też powstają nowe kryteria. Taka edukacja dla człowieka ery cyfryzacji będzie też obietnicą spełnionego życia, czyli takiego, w którym człowiek wykorzystuje swoje zdolności, talenty i potencjał, angażując się w coś, co jest dla niego autentyczne i ważne (Seligman, Csikszentmihalyi, 2000: 11). Filozofia człowieka leżąca u fundamentów edukacji XXI w. musi zakreślać coraz to nowe, ale elastyczne granice, zdając sobie sprawę, że umiejętności i pasje ucznia, kiedyś leżące poza jej granicami, w najbliższej przyszłości mogą się okazać kluczowe. Potrzebuje wskazywać wartości, nie tylko nauczając o nich, lecz dając przykład ich realizacji w codziennym życiu. Dziś młode pokolenia kwestionują wartości nie dla nich samych, lecz dlatego, że pozostają często wartościami w teorii. Młodzi potrzebują moralnego kręgosłupa wybranego w wolności, a nie narzuconego siłą tradycji i nakazu: „Tak było zawsze, więc tak musisz”. Człowiek początku ery cyfryzacji jest narażony na gubienie własnej tożsamości, bo oświata podaje mu rozwiązania 
i wiedzę wcześniejszego pokolenia, a edukacja jest nastawiona na uczenie tego, co było, a nie tego, co jest. Systemy oświaty zazwyczaj przekazują przecież wiedzę wcześniejszego pokolenia. Do tej pory praktyka ta była wystarczająca. Świat XXI w. pędzi jednak zbyt szybko. Ludzie odpowiedzialni za nauczanie muszą być świadomi, że dzisiaj edukacja ma wychowywać do świata, którego jeszcze nie ma. Wychowujemy zatem do nieznanego (Furr, Dyer, 2014). Doskonale wpisuje się w ten obraz doświadczenie globalnej pandemii COVID-19. W ciągu zaledwie kilku tygodni cały świat znalazł się w nowej rzeczywistości, do której jako ludzkość nie mieliśmy szans się przygotować. Od dwóch dekad w biznesie, zarządzaniu i edukacji podejmuje się temat świata VUCA (akronim od ang. słów: volatility, uncertainty, complexity, ambiguity) (Krawczyńska-Zaucha, 2019: 223-224), podając rozmaite przykłady różnych jego składowych. Jednak dopiero międzynarodowa kwarantanna i piętrzące się w związku z nią wyzwania stojące przez edukatorami, dziećmi czy rodzicami naprawdę przekonały ludzkość, że zmiany w dzisiejszym świecie następują nieoczekiwanie i na ogromną skalę. Owo bezprecedensowe wydarzenie obnażyło wszystkie braki, błędne założenia i nieadekwatne cele edukacji. Postawiło również pytanie o filozofię, która stoi u ich fundamentów, o adekwatność przyjętych założeń otaczającej nas rzeczywistości.

Świat XXI w. stawia wiele wyzwań zarówno przed filozofią, jak i edukacją. Niezmiernie ważne jest, aby filozofia w rzeczywistości VUCA była otwarta, aby nie patrzyła tylko wstecz, szukając w przeszłych rozwiązaniach wskazówek do nieznanych wcześniej zagadnień, lecz by z odwagą sama kreśliła przyszłość, była falą, która będzie wyznaczać nowe drogi rozwoju nauk i kierunków myślenia, która śmiało stawi czoło nieznanemu. Tak było u jej początków, umiłowanie mądrości to nic innego jak życie pełne ciekawości i pasji, dokładnie takie, jakiego potrzebuje doświadczyć człowiek XXI w.

\section{Bibliografia}

Adorno T.W. (1978), Wychowanie po Oświęcimiu, „Znak”, nr 285.

Arystoteles (1996), Etyka nikomachejska, przeł. D. Gromska, w: Artystoteles, Dzieła wszystkie, t. 5, Warszawa.

Bank Światowy (2011), Fueling Growth and Competitiveness in Poland Through employment, skills and innovation, http://siteresources.worldbank.org/POLANDEXTN/Resources/304794-1300479015951/ Europe2020Poland.pdf [dostęp: 18.09.2017].

Camus A. (1971), Eseje, przeł. J. Guze, Warszawa.

Fry H. (2019), Hello world. Jak być człowiekiem w epoce maszyn?, Warszawa.

Furr N., Dyer J.H. (2014), Leading Your Team into the Unknown, „Harvard Business Review”, 12, https://hbr.org/2014/12/leading-your-team-into-the-unknown [dostęp: 16.11.2019]. 
Harari Y.N. (2018), 21 lekcji na XXI wiek, Warszawa.

Hatmaker T. (2017), Saudi Arabia bestows citizenship on a robot named Sophia, https://techcrunch. com/2017/10/26/saudi-arabia-robot-citizen-sophia/?guccounter=1\&guce_referrer_us=aHR0c HM6Ly9lbi53aWtpcGVkaWEub3JnLw\&guce_referrer_cs=NcvPuHe3ugg3L7IVs1uvJA [dostęp: 15.11.2019].

Heidegger M. (1931), Bycie i czas, przeł. B. Baran, Warszawa.

Hejnicka-Bezwińska T. (2015), Praktyka edukacyjna w warunkach zmiany kulturowej, Warszawa.

Januszewska E. (2002), Dojrzewanie do wolności w wychowaniu. Rzecz o A.S Neillu, Warszawa.

Jaspers K. (1932), Philosophie, t. 1-2, Berlin.

Kallas P. (2019), Top 15 Most Popular Social Networking Sites and Apps, https://www.dreamgrow. com/top-15-most-popular-social-networking-sites/ [dostęp: 15.11.2019].

Kosiorek M. (2010), Pedagogika autorytarna a podejście włączające w procesie kształcenia ucznia ze specjalnymi potrzebami edukacyjnymi, „Przegląd Badań Edukacyjnych”, 10-11, s. 143-151.

Krawczyńska-Zaucha T. (2019), A new paradigm of management and leadership in the VUCA world, „Scientific Papers of Silesian University of Technology Organization And Management Series”, 141, pp. 221-230.

Krawczyńska-Zaucha T. (2020), Przywództwo edukacyjne jako fundament zarzadzania oświata w świecie Vuca, w: Edukacja XXI wieku. Strategie zarządzania i kierunki rozwoju, red. T. Krawczyńska-Zaucha, Kraków.

Kwieciński Z., Śliwerski B. (red.) (2019), Pedagogika. Podręcznik akademicki, Warszawa.

McDermott R. (red.) (1984), The Essential Steiner: Basic writings of Rudolf Steiner, San Francisco.

Marcel G. (1962), Być i mieć, przeł. P. Lubicz, Warszawa.

de Mooij M. (2013), Global Marketing and Advertising: Understanding Cultural Paradoxes, LondonNew York-Singapore.

Neill A.S. (1969), Theorie und Praxis der antyautoritären Erzienhung, Hamburg.

Our Kids (2019), https://www.ourkids.net/pl/raport-o-szkolnictwie.php [dostęp: 15.11.2019].

Paoluš R. (1991), K filosofii vychovy, Praha.

Rawls J. (1994), Teoria sprawiedliwości, Warszawa.

Robinson K. (2012), Zmiana paradygmatu edukacji, https://www.youtube.com/watch?v=_wxc Xd5Cnv8 [dostęp: 15.11.2019].

Schaller K. (1977), Erziehung, „Wörterbuch der Pädagogik”, Bd. I.

Schulz L.E., Gopnik A. (2004), Causal learning across domains, „Developmental Psychology”, 40 (2), pp. 162-176, https://https://doi.org/10.1037/0012-1649.40 [dostęp: 16.11.2019].

Seligman M.E.P., Csikszentmihalyi M. (2000), Positive psychology. A an introduction, „American Psychologist", 55 (1), pp. 5-14.

Śliwerski B. (2019), Pedagogika jako nauka, w: Pedagogika. Podręcznik akademicki, red. Z. Kwieciński, B. Śliwerski, Warszawa.

Weller Ch. (2017), The first-ever robot citizen has 7 humanoid 'siblings' - here's what they look like, https://www.businessinsider.com/sophia-robot-hanson-robotics-other-humanoids2017-11?IR=T [dostęp: 15.11.2019]. 